\title{
Pengaruh Pengendalian Diri, Literasi serta Perilaku Keuangan Terhadap Kesejahteraan Keuangan
}

\author{
Leonardo Luis dan Nuryasman MN \\ Program Studi Manajemen Fakultas Ekonomi \& Bisnis \\ Universitas Tarumanagara \\ Email: leonardoluis221@gmail.com
}

\begin{abstract}
The purpose of this study is to determine whether the financial well-being of financial management student at Tarumanagara University can be measured through financial behavior, where the level of financial behavior in this study is seen based on self-control and financial literacy. This research uses primary data through the process of collecting data by sharing questionnaires online using google forms questionnaire with a non-probability sampling method of the type of convenience sampling with a total of 150 financial management student at Tarumanagara University. The data analysis technique used is Structural Equation Modeling (SEM) with Smart-PLS program version 3.2.8. The results of this study show that there is a positive and significant influence between self-control, literacy, and financial behavior towards financial well-being.
\end{abstract}

Keywords: Self-control, Financial Literacy, Financial Behavior, Financial Well-being.

Tujuan penelitian ini adalah untuk mengetahui apakah kesejahteraan keuangan mahasiswa manajaemen keuangan Universitas Tarumanagara dapat diukur melalui perilaku keuangannya, dimana tingkat perilaku keuangan dalam penelitian ini dilihat berdasarkan pengendalian diri dan literasi keuangan seseorang. Penelitian ini menggunakan data primer melalui proses pengumpulan data dengan cara membagikan kuesioner secara online menggunakan google form dengan metode non-probability sampling berjenis convenience sampling dengan total 150 responden mahasiswa manajemen keuangan Universitas Tarumanagara. Teknik analisis data yang digunakan adalah Structural Equation Modeling (SEM) dengan program Smart-PLS versi 3.2.8. Hasil dari penelitian ini menunjukkan bahwa terdapat pengaruh positif dan signifikan antara pengendalian diri, literasi, serta perilaku keuangan terhadap kesejahteraan keuangan.

Kata kunci: Pengendalian Diri, Literasi Keuangan, Perilaku Keuangan, Kesejahteraan Keuangan

\section{LATAR BELAKANG}

Mahasiswa merupakan satu dari banyaknya komponen pada masyarakat yang jumlahnya cukup besar dan bisa memberikan pengaruh besar terhadap perekonomian karena dikemudian hari mahasiswa akan memasuki dunia kerja dan mulai mandiri termasuk dalam pengelolaan keuangannya (Arsanti \& Riyadi, 2019). Berdasarkan hal tersebut mahasiswa berada dalam fase dimana mereka harus mandiri dan mulai untuk mengelola keuangan mereka tanpa pengawasan penuh dari orang tua (Akben-Selcuk, 2015)

Berdasarkan penelitian yang dilakukan oleh (Rachmawati \& Nuryana, 2020) ditemukan bahwa tidak banyak mahasiswa yang melakukan pengelolaan keuangan pribadi, hal ini didukung dengan penelitian yang dilakukan (Ohio State News, 2015) membuktikan bahwa mayoritas mahasiswa khawatir terhadap keuangan pribadi mereka dikarenakan tidak ada penghematan untuk kebutuhan yang mendesak, dan kurangnya perencanaan keuangan sehingga mahasiswa cenderung berperilaku boros. kebiasaan berbelanja ini pada masyarakat bisa berakibat buruk bagi kesejahteraan keuangan (Kompas.com, 2017)

Financial Well-Being atau kesejahteraan keuangan merupakan keadaan di mana seseorang dapat sepenuhnya memenuhi kewajiban saat ini dan berkelanjutan, serta dapat merasa aman 
akan keuangan mereka di masa depan, dan mampu membuat pilihan untuk menikmati hidup (OECD, 2016). Kesejahteraan keuangan sangatlah penting, karena dengan adanya kesejahteraan keuangan yang dimiliki seseorang dapat memberikan rasa aman bagi pemiliknya (CFPB, 2015).

Pada dasarnya, kesejahteraan keuangan pada mahasiswa tidak mudah dicapai, menurut Vlaev \& Elliott (2014) kesejahteraan keuangan dipengaruhi atas pengelolaan keuangan individu, di mana orang tersebut mempunyai kontrol terhadap aspek-aspek keuangannya sehingga mereka dapat mengelola keuangannya dengan baik. Selain itu, Zemtsov et al. (2015) menyatakan bahwa kesejahteraan keuangan bergantung terhadap perilaku keuangan dan aliran pendapatan yang dihasilkan oleh aset yang dimiliki. Hal ini didukung oleh Otoritas Jasa Keuangan (OJK, 2017) yang menyatakan bahwa seseorang yang memiliki kesejahteraan keuangan yang baik maka memerlukan kemampuan pengelolaan keuangan dan kemampuan untuk berinvestasi serta memiliki ketahanan keuangan yang baik juga.

Terdapat beberapa variabel yang dapat mempengaruhi kesejahteraan keuangan salah satunya adalah pengendalian diri (Self-Control). Berdasarkan hasil penelitian yang telah dilakukan oleh Strömbäck et al. (2017) menjelaskan bahwa adanya pengaruh positif pengendalian diri terhadap perilaku keuangan dan kesejahteraan keuangan.

Variable lain yang dapat mempengaruhi kesejahteraan keuangan yaitu literasi keuangan (Financial Literacy). Moein Addin et al. (2013) berpendapat bahwa literasi keuangan dapat mempengaruhi kesejahteraan keuangan individu dan menjauhkan individu dari rasa kekhawatiran keuangan.

Berdasarkan hasil penelitian yang dilakukan oleh Philippas \& Avdoulas (2020) membuktikan bahwa adanya pengaruh yang positif perilaku keuangan terhadap kesejahteraan keuangan, mahasiswa yang memiliki literasi keuangan dan perilaku keuangan yang tinggi memiliki kemungkinan yang tinggi pula untuk mencapai kesejahteraan keuangan.

\section{KAJIAN TEORI}

Dasar teori (Theory of Planned Behavior) dikembangkan oleh Ajzen (1991) yang digunakan dalam penelitian ini bertujuan untuk memprediksi dan memahami perilaku individu. Berdasarkan teori perilaku terencana, perilaku individu ditentukan melalui niat atau intensi individu tersebut. Intensi tersebut didasari oleh sikap terhadap perilaku seseorang, norma subjektif dan kepentingan relatif antara sikap dan norma subjektif. kaitan TPB dengan penelitian ini yaitu menjelaskan terjadinya tindakan manusia yang dipengaruhi pengendalian diri pada seseorang. Teori ini menjelaskan bahwa perilaku tidak sepenuhnya dibawah pengaruh dari individu, tetapi seseorang dapat bertindak dari segi psikologi didalam berbagai faktor yang dapat mempengaruhi terbentuknya perilaku, hal ini yang melandasi bahwa kesejahteraan keuangan yang dipengaruhj perilaku keuangan dengan faktor psikologis yang mempengaruhinya.

Pengendalian Diri. Menurut Younas \& Farooq (2019) pengendalian diri membantu seseorang dalam mengambil keputusan dan tekat yang kuat sehingga seseorang dapat menjadi orang yang berpengaruh atau sejahtera secara keuangan. Sebaliknya kurangnya pengendalian diri pada seseorang dapat mengakibatkan pengambilan keputusan yang tidak rasional kurangnya percaya diri dan memiliki perilaku yang buruk.

Literasi Keuangan. Rai et al. (2019) dan Vitt et al. (2000) dalam (Tsounis \& Aspasia, 2017) literasi keuangan adalah kemampuan seseorang dalam membaca, menganalisa, serta mengambil keputusan terkait keuangan dengan memanfaatkan uang secara efektif dan efisien untuk mencapai kesejahteraan keuangan. 
Perilaku Keuangan. Menurut Kholilah \& Iramani (2013) dalam (Setiyani \& Solichatun, 2019) dapat diketahui bahwa perilaku keuangan adalah sebuah kemampuan seseorang dalam melakukan perencanaan, penganggaran, mengontrol, menggunakan, mencari dan menyimpan keuangan sehari-hari.

Kesejahteraan Keuangan. Selanjutnya menurut CFPB (2015) serta Younas \& Farooq (2019) kesejahteraan keuangan adalah keadaan dimana seseorang telah mampu memenuhi kewajiban keuangannya saat ini maupan di masa depan melalui pengendalian diri untuk hidup sejahtera dan sehat, secara keuangan dan emosional dalam hidupnya.

Kaitan antara Pengendalian Diri dengan Perilaku Keuangan. Menurut (Strömbäck et al., 2017) adanya pengaruh positif pengendalian diri terhadap perilaku keuangan. Orang-orang yang memiliki pengendalian diri yang baik akan memiliki perilaku keuangan yang baik pula dan dengan pengendalian diri seseorang dapat menjaga sumber keuangan mereka dengan baik. Hasil ini didukung dengan penelitianyang dilakukan Hirvonen, (2018) menunjukan adanya pengaruh positif pengendalian diri teradap perilaku keuangan.

Kaitan antara Literasi Keuangan dengan Perilaku Keuangan. Menurut Laily (2016), dan Sundarasen et al. (2016) adanya pengaruh positif dan signifikan antara literasi keuangan terhadap perilaku managemen keuangan. Hasil penelitian tersebut didukung dengan penelitian yang dilakukan oleh Setiyani \& Solichatun (2019) yang mengungkapkan adanya pengaruh positif literasi keuangan terhadap perilaku keuagan.

Kaitan antara Pengendalian Diri dengan Kesejahteraan Keuangan. Berdasarkan penelitian yang dilakukan oleh Strömbäck et al. (2017) adanya pengaruh positif pengendalian diri terhadap kesejahtaraan keuangan. Orang yang mempunyai pengendalian diri yang baik memiliki kebiasaan menabung, sehingga dapat dikatakan orang yang memiliki pengendalian diri yang baik mereka lebih siap untuk mengelola pengeluaraan yang tidak terduga dan lebih cenderung mempunyai simpanan yang cukup untuk masa pensiun.

Kaitan antara Literasi Keuangan dengan Kesejahteraan Keuangan. Menurut pelenilitian yang dilakukan oleh Setiyani \& Solichatun (2019) menunjukan adanya pengaruh positif antara literasi keuangan dengan kesejahteraan keuangan. Penelitian tersebut didukung dengan adanya penelitian yang dilakukan oleh Younas \& Farooq (2019); (Fazli Sabri et al., 2012) yang menunjukan adanya pengaruh positif dan signifikan antara literasi keuangan terhadap kesejahteraan keuangan pada mahasiswa.

Kaitan antara Perilaku Keuangan dengan Kesejahteraan Keuangan. Pada penelitian yang dilakukan Setiyani \& Solichatun (2019) menyatakan bahwa perilaku keuangan memiliki pengaruh yang positif dan signifikan terhadap kesejateraan keuangan pada mahasiswa. Dengan membuat anggaran pribadi mahasiswa dapat menentukan prioritas mereka dalam berbelanja dan tidak melakukan pembelian yang kompulsif sehingga dapat meningkatkan rasa aman teradap keuangan mereka

Kaitan antara Pengendalian diri dengan Kesejahteraan Keuangan melalui variabel mediasi Perilaku Keuangan. Menurut penelitian yang dilakukan oleh (Strömbäck et al., 2017) menjelaskan bahwa pengendalian diri tidak hanya berpengaruh terhadap perilaku keuangan tetapi juga dapat berpengaruh terhadap kesejahteraan keuangan, dengan adanya pengendalian diri yang baik dapat membawa perilaku keuangan yang baik pula, yang dapat memberikan efek positif pada kesejahteraan keuangan. 
Kaitan antara Literasi Keuangan dengan Kesejahteraan keuangan melalui variabel mediasi Perilaku Keuangan. Berdasarkan hasil penelitian yang sudah dilakukan oleh Setiyani \& Solichatun (2019) ; Younas \& Farooq (2019) menunjukan bahwa adanya pengaruh positif antara literasi keuangan terhadap kesejahteraan keuangan melalui perilaku keuangan pada mahasiswa, tetapi pengaruh literasi keuangan secara langsung terhadap kesejateraan keuangan memiliki pengaruh yang lebih besar dari pada melewati mediasi

Berdasarkan uraian kaitan antar variabel diatas, maka terbentuk kerangka pemikiran sebagai berikut:

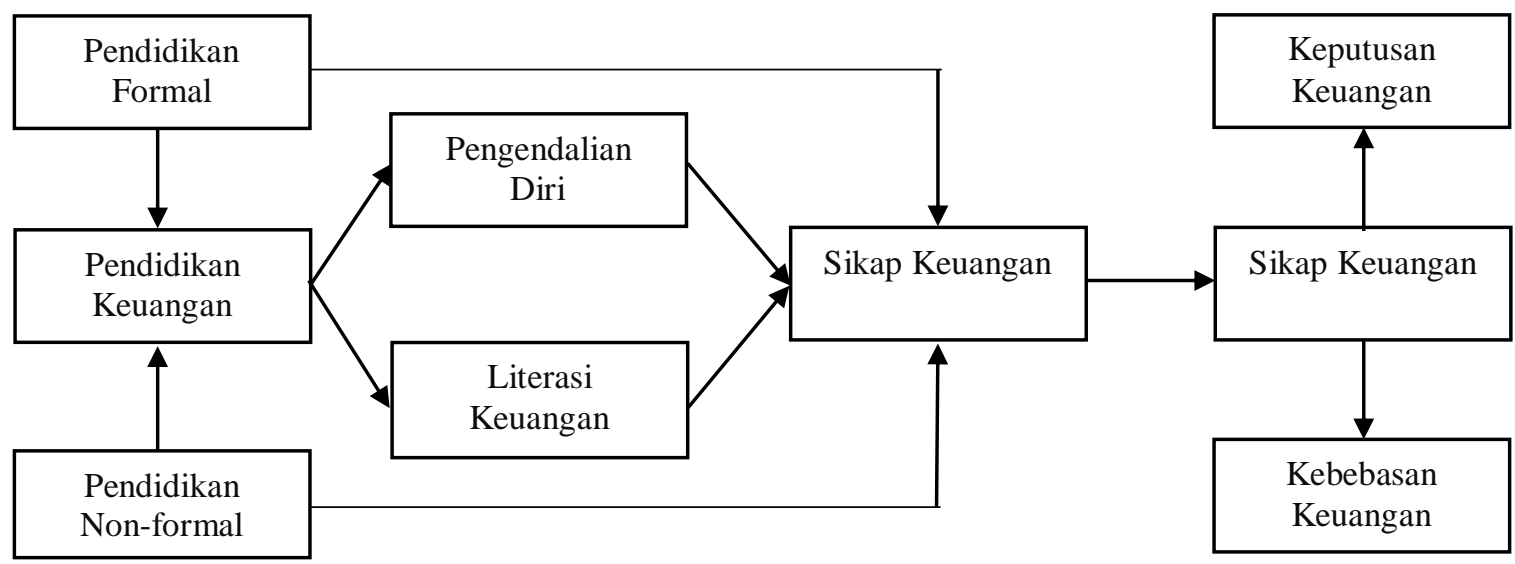

Gambar 1. Kerangka Pemikiran

H1: Terdapat pengaruh Pengendalian Diri terhadap Perilaku Keuangan.

H2: Terdapat pengaruh Literasi Keuangan terhadap Perilaku Keuangan.

H3: Terdapat pengaruh Pengendalian diri terhadap Kesejahteraan Keuangan.

H4: Terdapat pengaruh Literasi Keuangan terhadap Kesejahteraan Keuangan.

H5: Terdapat pengaruh Perilaku Keuangan terhadap Kesejahteraan Keaungan.

H6: Terdapat pengaruh Pengendalian Diri terhadap Kesejahteraan Keuangan melalui variabel Mediasi Perilaku Keuangan.

H7: Terdapat pengaruh Literasi Keuangan terhadap Kesejahteraan Keuangan melalui variabel Mediasi Perilaku Keuangan.

\section{METODOLOGI}

Desain penelitian ini adalah penelitian deskripstif dengan metode cross-sectional design dengan populasinya adalah Mahasiswa Manajemen Keuangan Universitas Tarumanagara yang berstatus aktif dengan total sampel berjumlah 150 responden. Metode pengambilan sampel pada penelitian ini adalah metode non-probability sampling dengan teknik convenience sampling. Data yang digunakan dalam penelitian ini adalah data primer yang diperoleh dari responden melalui kuesioner online yang dibuat menggunakan google form.

Berdasarkan data yang telah dikumpulkan, diketahui bahwa responden pada penelitian ini mayoritas berjenis kelamin pria sebanyak 82 orang $(54,7 \%)$ dan sisanya wanita sebanyak 68 orang $(45,3 \%)$. Dikelompokan lagi berdasarkan usianya. Usia 17-18 tahun sebanyak 5 orang $(3,3 \%)$, usia 19-20 tahun sebanyak 73 orang $(48,7 \%)$, usia 21-22 tahun sebanyak 66 orang $(44 \%)$ dan usia $>22$ tahun sebanyak 6 orang $(4 \%)$.

Sebagian besar responden dalam penelitian ini berdasarkan pendidikan terakhirnya sebanyak 143 orang (96\%) berpendidikan terakhir di bangku SMA, dan sebanyak 6 orang (4\%) berpendidikan terakhir vokasi (D3).

Selanjutnya, berdasarkan data yang telah terkumpul, pengeluaran perbulan Mahasiswa/i Manajemen Keuangan Universitas Tarumanagara dari 150 responden, yaitu sebanyak 47 orang 
(31,3\%) memiliki pengeluaran lebih kecil dari Rp 1.000.000, sebanyak 77 orang $(51,3 \%)$ memiliki pengeluaran antara $\mathrm{Rp} 1.000 .000$ sampai $\mathrm{Rp} 2.000 .000$, sebanyak 24 orang $(16 \%)$ memiliki pengeluaran antara $\mathrm{Rp} 2.000 .000$ sampai $\mathrm{Rp} 3.000 .000$ dan sisanya 2 orang $(1,3 \%)$ memiliki pengeluaran lebih dari Rp 3.000.000 perbulan.

\section{HASIL ANALISIS DATA}

\section{Uji validitas}

\section{Convergent validity}

Tabel 2. Hasil Analisis Average Variance Extracted (AVE)

\begin{tabular}{|c|c|}
\hline Variabel & AVE \\
\hline Pengendalian Diri & 0,627 \\
\hline Literasi Keuangan & 0,567 \\
\hline Perilaku Keuangan & 0,584 \\
\hline Kesejahteraan Keuangan & 0,665 \\
\hline
\end{tabular}

Tabel 2 menunjukan angka AVE yang telah berubah setelah mengeluarkan indikator yang tidak sesuai dengan kriteria (AVE $<0,5)$ dan hasilnya menunjukan bahwa seluruh indikator yang digunakan saat ini telah memenuhi kriteria (AVE >0,5). Karena apabila nilai average variance extracted (AVE) pada setiap variabel lebih besar dari 0,5 maka variabel pada penelitian ini dapat diikutsertakan (Henseler et al. (2009). Sehingga dapat disimpulkan penelitian ini lolos pengujian convergent validity.

Tabel 3. Hasil Nilai Loading Factor

\begin{tabular}{|c|c|c|c|c|}
\hline Indikator & $\begin{array}{c}\text { Kesejahteraan } \\
\text { Keuangan } \\
\text { (KK) }\end{array}$ & $\begin{array}{c}\text { Literasi } \\
\text { Keuangan } \\
\text { (LK) }\end{array}$ & $\begin{array}{c}\text { Pengendalian } \\
\text { Diri } \\
\text { (PD) }\end{array}$ & $\begin{array}{c}\text { Perilaku } \\
\text { Keuangan } \\
\text { (PK) }\end{array}$ \\
\hline KK1 & 0.840 & & & \\
\hline KK2 & 0.815 & & & \\
\hline KK3 & 0.857 & & & \\
\hline KK4 & 0.763 & & & \\
\hline KK5 & 0.799 & & & \\
\hline LK1 & & 0.739 & & \\
\hline LK2 & & 0.738 & & \\
\hline LK3 & & 0.785 & & \\
\hline LK4 & & 0.719 & & 0.788 \\
\hline LK5 & & 0.782 & & 0.811 \\
\hline PD3 & & & 0.796 & 0.703 \\
\hline PD4 & & & 0.763 & \\
\hline PD5 & & & & \\
\hline PK3 & & & & \\
\hline PK4 & & & & \\
\hline PK5 & & & & \\
\hline PK6 & & & & \\
\hline
\end{tabular}

Berdasarkan tabel 3 diatas maka dapat diketahui bahwa seluruh indikator pada variabel eksogen dan endogen menunjukan angka yang positif dan sudahmemenuhi kriteria yaitu nilai 
lebih besar dari 0,7 (Loading factor > 0,7). Maka dapat disimpulkan bahwa seluruh indikator dapat digunakan dalam penelitian ini.. Berdasarkan tabel 3 seluruh indikator variabel eksogen telah memenuhi kriteria sehingga seluruh indikator dapat digunakan dalam penelitian ini.

\section{Uji Reabilitas}

Analisis reabilitas dilakukan dengan memperhatikan nilai dari Cronbach's Alpha dan Composite Reability yang ditunjukan pada taebl 4 dibawah ini.

Tabel 4. Hasil Analisis Reabilitas

\begin{tabular}{|c|c|c|}
\hline Variabel & Composite Reliability & Cronbach's Alpha \\
\hline Kesejahteraan Keuangan & 0.908 & 0,873 \\
\hline Literasi Keuangan & 0.868 & 0,809 \\
\hline Pengendalian Diri & 0,834 & 0,702 \\
\hline Perilaku Keuangan & 0,848 & 0,761 \\
\hline
\end{tabular}

Berdasarkan tabel 4 seluruh indikator pada variabel dalam penelitian ini memenuhi kriteria reabilitas instrumen karena hasil kalkulasi nilai composite reability lebih besar dari 0,7 dan cronbach's alpha lebih besar dari 0,6.

\section{Koefisien Determinasi (R-Square)}

Koefisien determinasi digunakan dalam suatu penelitian untuk mengetahui besarnya kontribusi suatu variabel eksogen terhadap variabel depennya yang ada. Dalam penelitian ini, nilai koefisien determinasi diperoleh dari variabel pengendalian diri dan literasi keuangan terhadap perilaku keuangan serta pengendalian diri dan literasi keuangan terhadap kesejahteraan keuangan.

Tabel 5. Hasil Koefisiensi Determinasi

\begin{tabular}{|c|c|}
\hline Variabel & R-Square \\
\hline Kesejahteraan Keuangan & 0,777 \\
\hline Perilaku Keuangan & 0,596 \\
\hline
\end{tabular}

Berdasarkan hasil koefisiensi determinasi di atas pada tabel 5, maka dapat diketahui bahwa nilai R-Square pada variabel kesejahteraan keuangan adalah sebesar 0,777 yang menunjukan bahwa sebesar $77,7 \%$ variabel kesejahteraan keuangan dapat dijelaskan oleh pengendalian diri, literasi serta perilaku keuangan, sedangkan sisanya 22,3\% (100\% - 77,7\%) dijelaskan oleh variabel-variabel lainnya yang tidak termasuk dalam model penelitian ini. Selain itu nilai R-Square pada variabel perilaku keuangan yaitu sebesar 59,6\% yang menunjukan bahwa variabel perilaku keuangan dapat dijelaskan oleh pengendalian diri dan literasi keuangan, sedangkan 40,4\% (100\% - 59,6\%) dapat dijelaskan oleh variabel-variabel lainnya yang tidak termaksuk dalam model penelitian ini. Berdasarkan kriteria yang dijelaskan Hair et al. (2011), R-Square kesejahteraan keuangan pada penelitian ini menunjukan nilai 0,777 yang tergolong substantial, sedangkan R-Square perilaku keuangan pada penelitian ini menunjukan angka 0,596 yang tergolong moderate.

\section{Hasil Pengujian Hipotesis}

Pengujian hipotessis pada penelitian ini dilakukan untuk melihat apakah hipotesis yang telah disajikan dapat diterima atau tidak. Menurut Hair et al. (2011) dan Henseler et al. (2009) menjelaskan bahwa pengujian hipotesis penelitian yang menggunakan PLS-SEM dilakukan dengan melihat nilai t-statistik yang terdapat pada analisis jalur antara variabel (path analysis) 
yang merupakan hasil dari metode bootstrapping. Hipotesis penelitian dapat diterima (tidak ditolak) apabila nilai $t$-statistic lebih besar dari 1,96 ( $t$-statistic $>1,96 ; \alpha=5 \%$ ). Hipotesis penelitian akan ditolak jika nilai $t$-statistic kurang dari 1,96 . Hasil analisi data secara singkat tertera pada Tabel 6 berikut ini:

Tabel 6. Hasil Pengujian Hipotesis

\begin{tabular}{|l|l|c|c|c|c|}
\hline \multirow{2}{*}{\multicolumn{2}{|c|}{ Variabel }} & \multicolumn{3}{c|}{ Kesejahteraan Keuangan } \\
\cline { 3 - 6 } \multicolumn{2}{|c|}{} & $\begin{array}{c}\text { Path } \\
\text { Coefficient }\end{array}$ & $\begin{array}{c}\text { Indirect } \\
\text { Effect }\end{array}$ & t-statistic & p-value \\
\hline H1 & Mediating Effect 1 & 0,2777 & - & 3,148 & 0,002 \\
\hline H2 & Mediating Effect 2 & 0,542 & - & 6,423 & 0,000 \\
\hline H3 & Pengendalian Diri & 0,246 & - & 3,333 & 0,001 \\
\hline H4 & Literasi Keuangan & 0,391 & - & 4,650 & 0,000 \\
\hline H5 & Perilaku Keuangan & 0,335 & - & 4,086 & 0,000 \\
\hline H6 & Indirect Mediating Effect 1 & - & 0,133 & 2,867 & 0,004 \\
\hline H7 & Indirect Mediating Effect 2 & - & 0,068 & 2,370 & 0,018 \\
\hline
\end{tabular}

Berdasarkan tabel 6 ditarik kesimpulan bahwa variabel pengendalian diri dan literasi keuangan memiliki pengaruh positif dan signifikan terhadap perilaku keuangan keuangan (Mediating Effect 1 \& 2) karena telah memenuhi kriteria pengujian hipotesis, selanjutnya variabel pengendalian diri dan literasi keuangan memiliki pengaruh terhadap kesejahteraan keuangan secara langsung karena telah memenuhi kriteria pengujian hipotesis serta variabel pengendalian diri dan literasi keuangan memiliki pengaruh positif dan signifikan terhadap kesejahteraan keuangan melalui variabel mediasi perilaku keuangan (Indirect Mediating Effect $1 \&$ 2) karena telah memenuhi kriteria pengujian hipotesis.

\section{DISKUSI DAN KESIMPULAN}

\section{Pengaruh Pengendalian Diri terhadap Perilaku Keuangan}

Berdasarkan hasil analisis data pada penelitian ini, menunjukan bahwa pengendalian diri memiliki pengaruh positif dan signifikan terhadap perilaku keuangan

Hal tersebut didukung oleh indikator pengendalian diri yang paling mempengaruhi perilaku keuangan yaitu individu selalu tepat waktu dalam mengerjakan pekerjaannya. Tanpa adanya pengendalian diri yang kuat dalam diri seseorang, maka akan mengakibatkan penurunanya produktifitas kerja pada diri seseorang pula.

Hasil penelitian ini sejalan dengan penelitian Strömbäck et al. (2017) adanya pengaruh positif pengendalian diri terhadap perilaku keuangan. Orang-orang yang memiliki pengendalian diri yang baik akan memiliki perilaku keuangan yang baik pula dan dengan pengendalian diri seseorang dapat menjaga sumber keuangan mereka dengan baik.

\section{Literasi Keuangan dengan Perilaku Keuangan}

Berdasarkan hasil penelitian ini maka literasi keuangan menunjukan pengaruh yang positif dan signifikan terhadap perilaku keuangan.

Indikator literasi keuangan yang paling mempengaruhi perilaku keuangan adalah individu memiliki pengetahuan yang baik mengenai kartu kredit dan manfaat menabung. Seseorang yang dapat mengatur keuangan seperti pemeriksaan, pengelolaan, serta pengendalian keuangan mereka sehari-hari dapat dikatakan memiliki perilaku keuangan yang baik selain itu seseorang dapat dikatakan memiliki perilaku keuangan yang bertanggungjawab jika individu dapat melakukan kegiatan menabung agar mengurangi kecenderungan seseorang dalam melakukan peminjaman dengan biaya yang tinggi untuk tercapainya kesejahteraan. 
Hasil penelitian ini sejalan dengan penelitian yang dilakukan oleh Setiyani \& Solichatun (2019) yang mengungkapkan adanya pengaruh positif antara literasi keuangan terhadap perilaku keuagan. Seseorang mempunyai pemahaman literasi keuangan yang tinggi maka semakin baik juga perilaku managemen keuangan yang dimiliki seseorang

\section{Pengaruh Pengendalian Diri terhadap Kesejahteraan Keuangan}

Berdasarkan hasil penelitian yang dilakukan pada penelitian ini maka dapat disimpulkan bahwa pengendalian diri memiliki pengaruh yang positif dan signifikan terhadap kesejahteraan keuangan secara langsung

Salah satu indikator pengendalian diri yang mempengaruhi kesejahteraan keuangan adalah individu mampu menahan dari godaan berbelanja yang berlebihan atau yang biasa disebut dengan pembelanjaan impulsif. Seseorang yang memiliki pengendalian diri yang baik dalam mengelola keuangannya dapat membantu diri untuk mengambil keputusan yang rasional, meningkatkan percaya diri dan menghindari perilaku yang buruk.

Strömbäck et al. (2017) adanya pengaruh positif pengendalian diri terhadap kesejahtaraan keuangan. Orang yang mempunyai pengendalian diri yang baik memiliki kebiasaan menabung, sehingga dapat dikatakan bahwa orang yang memiliki pengendalian diri lebih cenderung mempunyai simpanan yang cukup untuk masa pensiun.

\section{Pengaruh Literasi Keuangan terhadap Kesejahteraan Keuangan}

Hasil pada penelitian ini menunjukan bahwa adanya pengaruh yang literasi keuangan terhadap kesejahteraan keuangan secara positif dan signifikan

Salah satu indikator literasi keuangan yang mempengaruhi kesejahteraan keuangan adalah individu memiliki pemahaman yang baik dalam menabung dan bertransaki. Literasi keuangan pada seseorang dapat diukur berdasarkan dimensi perilaku, keahlian, pengetahuan dan sikap. Dari hal tersebut, dapat dikatakan bahwa seseorang yang memiliki literasi keuangan yang baik maka mereka mampu mengambil keputusan yang efektif mengenai penggunaan dan pengelolaan uang yang mereka miliki secara efektif dan efisien untuk mencapai kesejahteraan keuangan.

Penelitian ini sejalan dengan penelitian yang dilakukan oleh Setiyani \& Solichatun (2019) menunjukan adanya pengaruh positif antara literasi keuangan dengan kesejahteraan keuangan

\section{Pengaruh Perilaku Keuangan terhadap Kesejahteraan Keuangan}

Hasil pada penelitian ini menunjukan bahwa terdapat hasil yang positif dan signifikan perilaku keuangan terhadap kesejahteraan keuangan.

Salah satu indikator perilaku keuangan yang memiliki pengaruh terhadap kesejahteraan keuangan pada penelitian ini adalah selalu mencatat pengeluaran bulanan saya secara rutin. Seseorang yang membuat anggaran pribadi mahasiswa dapat menentukan prioritas mereka dalam berbelanja dan tidak melakukan pembelian yang kompulsif sehingga dapat meningkatkan rasa aman teradap keuangan mereka.

Hasil pengujian yang dilakukan pada penelitian ini sesuai dengan penelitian yang dilakukan oleh Setiyani \& Solichatun (2019) menyatakan bahwa perilaku keuangan memiliki pengaruh yang positif dan signifikan terhadap kesejateraan keuangan pada mahasiswa.

\section{Pengaruh Pengendalian Diri terhadap Kesejahteraan Keuangan melalui Variabel Mediasi Perilaku Keuangan}

Berdasarkan hasil penelitian ini maka pengendalian diri menunjukan pengaruh yang positif dan signifikan terhadap kesejahteraan keuagnan.

Salah satu indikator pengendalian diri yang mempengaruhi kesejahteraan keuangan adalah individu mampu menahan dari godaan berbelanja yang berlebihan. Berdasarkan penelitian yang dilakukan maka dapat diketahui bahwa mahasiswa secara umum mempunyai penghasilan dalam setiap bulannya dan memiliki pemahaman yang cukup baik pengaruh dari menabung 
dan berinvestasi, maka disaat pengeluaran tidak terduga muncul mereka mampu menggunakan tabungan yang mereka miliki untuk membayar keperluan mendesak. Hal ini didukung dengan jawaban setuju responden pada salah satu indikator kesejahteraan keuangan yaitu individu bisa menangani pengeluaran besar yang tidak terduga.

Hasil penelitian ini sejalan dengan hasil penelitian Strömbäck et al. (2017) dan Younas \& Farooq (2019) yang menjelaskan bahwa pengendalian diri tidak hanya berpengaruh terhadap perilaku keuangan tetapi juga dapat berpengaruh terhadap kesejahteraan keuangan, dengan adanya pengendalian diri yang baik pada diri seseorang maka dapat membawa perilaku keuangan yang baik pula, yang dapat memberikan efek positif pada kesejahteraan keuangan.

\section{Pengaruh Literasi Keuangan terhadap Kesejahteraan Keuangan melalui Variabel Mediasi Perilaku Keuangan}

Berdasarkan hasil penelitian ini maka literasi keuangan menunjukan pengaruh yang positif dan signifikan terhadap kesejahteraan keuangan.

Salah satu indikator literasi keuangan yang mempengaruhi kesejahteraan keuangan adalah individu merasa mengelola keuangan pribadi adalah hal yang penting. Literasi keuangan merupakan kombinasi kesadaran, pengetahuan, keterampilan, sikap dan perilaku yang diperlukan sehingga seseorang mampu mengelola dan mengambil keputusan keuangan dengan baik untuk mencapai kesejahteraan keuangan. Hal ini didukung dengan jawaban responden pada indikator kesejahteraan keuangan yaitu individu dapat menikmati hidup karena cara saya mengelola uang dengan baik.

Penelitian ini juga sejalan dengan penelitian yang dilakukan oleh Philippas \& Avdoulas (2020) juga membuktikan bahwa adanya pengaruh perilaku keuangan terhadap kesejahteraan keuangan.

\section{SARAN}

Terkait dengan keterbatasan dan hasil penelitian ini, maka saran yang dapat diberikan adalah sebagai berikut:

1. Bagi peneliti berikutnya, disarankan untuk menambahkan jumlah indikator, jumlah pengambilan sampel serta variabel-variabel lainnya seperti pengetahuan keuangan, pendapatan, variabel demografis, dan variabel lainnya yang bertujuan untuk mendukung setiap kontruk pada penelitian, mendapatkan data yang lebih akurat serta dapat menunjukan pengaruh yang lebih baik terhadap kesejahteraan keuangan.

2. Bagi mahasiswa/i, disarankan untuk memperhatikan beberapa aspek yang ada sehingga mampu mencapai kesejahteraan keuangan dimasa depan seperti, kesadaran akan pentingnya pengendalian diri, literasi keuangan serta perilaku keuangan yang dapat ditingkatkan melalui edukasi keuangan yang dapat diperoleh dari pendidikan formal dapat berasal dari sekolah, kuliah, seminar, dan lain-lain. Sedangkan nonformal bisa berasal dari pengalaman pribadi, saudara, orang tua, teman-teman, lingkungan sekitar dan lain sebagainya. Sehingga sangat disarankan mahasiswa/i tetap aktif dalam melakukan kegiatan yang berdampak positif bagi dirinya demi tercapainya kesejahteraan keuangan.

3. Bagi akademisi, disarankan untuk menambah kegiatan akademisi seperti mengadakan edukasi lebih mendalam berupa seminar terhadap perencanaan keuangan serta penggunaan produk-produk keuangan seperti fintech, dan lain sebagainya dalam rangka meningkatkan kemampuan mahasiswa untuk mencapai kesejahteraan dimasa datang. 


\section{DAFTAR PUSTAKA}

(CFPB), C. F. P. B. (2015). Financial Well Being: The Goal of Financial Education. January, 48. http://files.consumerfinance.gov/f/201501_cfpb_report_financial-well-being.pdf

(OJK), O. J. K. (2017). Laporan Kinerja Otoritas Jasa Keuangan 2017.

Ajzen, I. (1991). The theory of planned behavior. Organizational Behavior and Human Decision Processes. https://doi.org/10.1016/0749-5978(91)90020-T

Akben-Selcuk, E. (2015). Factors Influencing College Students' Financial Behaviors in Turkey: Evidence from a National Survey. International Journal of Economics and Finance, 7(6), 87-94. https://doi.org/10.5539/ijef.v7n6p87

Arsanti, C., \& Riyadi, S. (2019). Analisis Pengaruh Literasi Keuangan Terhadap Perilaku Keuangan Mahasiswa. 3(2), 110-122.

Fazli Sabri, M., Cook, C. C., \& Gudmunson, C. G. (2012). Financial well- being of Malaysian college students. Asian Education and Development Studies, 1(2), 153-170. https://doi.org/10.1108/20463161211240124

Hair, J. F., Ringle, C. M., \& Sarstedt, M. (2011). PLS-SEM: Indeed a silver bullet. Journal of Marketing Theory and Practice. https://doi.org/10.2753/MTP1069-6679190202

Hasibuan, B. K., Lubis, Y. M., \& HR, W. A. (2018). Financial Literacy and Financial Behavior as a Measure of Financial Satisfaction. https://doi.org/10.2991/ebic17.2018.79

Henseler, J., Ringle, C. M., \& Sinkovics, R. R. (2009). The use of partial least squares path modeling in international marketing. Advances in International Marketing. https://doi.org/10.1108/S1474-7979(2009)0000020014

Hirvonen, J. (2019). Financial behavior and well-being of young adults : effects of self-control and optimism Financial Behavior And Well-Being Of Young Adults : Effects Of SelfControl And Optimism University of Jyväskylä Jyväskylä School of Business and Economics Master 's. February.

Laily, N. (2016). Pengaruh Literasi Keuangan Terhadap Perilaku Mahasiswa Dalam Mengelola Keuangan. Journal of Accounting and Business Education. https://doi.org/10.26675/jabe.v1i4.6042

Moein Addin, M., Nayebzadeh, S., Kalantari Taft, M., \& mohammadi Sadrabadi, M. (2016). Financial strategies and investigating the relationship among financial literacy, financial well-being, and financial worry. European Online Journal of Natural and Social Sciences, 2(3(s)), 1279-1289.

OECD. (2016). OECD/INFE International Survey of Adult Financial Literacy Competencies. Oecd, $1-100$.

Philippas, N. D., \& Avdoulas, C. (2020). Financial literacy and financial well-being among generation-Z university students: Evidence from Greece. European Journal of Finance, 26(4-5), 360-381. https://doi.org/10.1080/1351847X.2019.1701512

Rachmawati, N., \& Nuryana, I. (2020). Peran Literasi Keuangan dalam Memediasi Pengaruh Sikap Keuangan dan Teman Sebaya Terhadap Perilaku Keuangan. Economic Education Analysis Journal, 9(1), 166-181. https://doi.org/10.15294/eeaj.v9i1.37246

Rai, K., Dua, S., \& Yadav, M. (2019). Association of Financial Attitude, Financial Behaviour and Financial Knowledge Towards Financial Literacy: A Structural Equation Modeling Approach. FIIB Business Review. https://doi.org/10.1177/2319714519826651

Setiyani, R., \& Solichatun, I. (2019). Financial Well-being of College Students: An Empirical Study on Mediation Effect of Financial Behavior. KnE Social Sciences, 3(11), 451. https://doi.org/10.18502/kss.v3i11.4026

Strömbäck, C., Lind, T., Skagerlund, K., Västfjäll, D., \& Tinghög, G. (2017). Does self-control predict financial behavior and financial well-being? Journal of Behavioral and Experimental Finance, 14, 30-38. https://doi.org/10.1016/j.jbef.2017.04.002 
Sundarasen, S. D. D., Rahman, M. S., Othman, N. S., \& Danaraj, J. (2016). Impact of financial literacy, financial socialization agents, and parental norms on money management. Advanced Science Letters.

Tsounis, N., \& Aspasia, V. (2017). Advances in Applied Economic Research. Proceedings of the 2016 International Conference on Applied Economics (ICOAF). Advances in Applied Economic Research, Springer Proceedings in Business and Economics. https://doi.org/10.1007/978-3-319-48454-9

Vitt, L. a., Kent, J., Lyter, D. M., Siegenthaler, J. K., \& Ward, J. (2000). Personal Finance and the Rush To Competence: Financial Literacy Education in the U.S. Personal Finance, January 2000, 1-234. https://doi.org/Fannie Mae Foundation: Washington DC

Vlaev, I., \& Elliott, A. (2014). Financial Well-Being Components. Social Indicators Research. https://doi.org/10.1007/s11205-013-0462-0

Younas, W., \& Farooq, M. (2019). Impact of Self-Control, Financial Literacy and Financial Behavior on Financial Well-Being. The Journal of Social Sciences Research, 5(51), 211-218. https://doi.org/10.32861/jssr.51.211.218

Zemtsov, A. A., Osipova, T. Y., \& Osipova, T. (2015). WELLSO 2015 -II International Scientific Symposium on Lifelong Wellbeing in the World Financial Wellbeing as a Type of Human Wellbeing: Theoretical Review. https://doi.org/10.15405/epsbs.2016.02.49 